\title{
New Working Organs for Solid Tillage of Fallow Fields in Summer Season
}

\author{
Viktor Rykov ${ }^{1}$, Sergey Kambulov ${ }^{1 *}$, and Sergey Belousov ${ }^{1,2}$ \\ ${ }^{1}$ Agrarian scientific center «Donskoy», department «North-Caucasus scientific-research institute of \\ agricultural mechanization and electrification», Zernograd, Russia \\ ${ }^{2}$ Kuban State Agrarian University named after I.T.Trubilin, Krasnodar, Russia
}

\begin{abstract}
The work is of an applied nature and is aimed at substantiating the need to develop the working bodies of the tool for processing steam fields in the summer to preserve moisture in the soil, the main technologies for processing steam are given, the working bodies of steam cultivators are grouped, the design of a new working body is proposed, consisting of 2 narrow one-sided paws, its description is given, the angles of setting the upper part of the working body in the transverse and longitudinal-vertical planes and the horizon are justified, in conclusion, the results of the work done are given.
\end{abstract}

\section{Justification of the need to develop the working bodies of the tool for fallow fields tillage in summer season}

Guaranteed high yields of winter crops, including winter wheat in conditions of lack of moisture, which is typical for the southern steppe zone of Russia, can be obtained only on fallow fields (in Rostov region in 2020 - 39 thousand hectares of fallow land, 16.1\% of arable land). In this regard, the tillage of fallow fields is the most important stage in obtaining high-quality food grain, especially in the summer and before sowing $[1,2]$.

Depending on soil and climatic conditions in the steppe zone of the North Caucasus, at least four main technologies of fallow tillage are used, which differ both in the method of main tillage (tilling and non-tilling) and in the time of its implementation (black, if the main tillage is carried out in the fall, and early, if the main tillage is carried out in the spring in the year of winter sowing) [3,4].

Famous Don scientists - farmers N. N. Borodin, I. G. Kalinenko in their works emphasize the need and importance of a layer by layer tillage of fallow fields from a great depth $(14-18 \mathrm{~cm})$ with a gradual decrease to 5-6 cm, so they approached the sowing time of winter crops.

They also consider "... unacceptable to till fallow fields in the second half of summer deeper than $8 \mathrm{~cm}$ ".

To ensure the depth of fallow fields tillage of 4-6 cm in the summer without removal of wet layers to the daytime surface by the present tillage machines and tools equipped with working bodies, usually in the form of pointed grips, is almost impossible. At the same

\footnotetext{
* Corresponding author: sergey_belousov_87@mail.ru
} 
time, the upper soil horizon is eventually dried up and the conditions for subsequent seed sowing in moist soil are not provided.

Currently, the proposed working bodies of tillers for continuous tillage (field tillers), which are conditionally referred to moisture-saving, can be divided in following groups (Table 1). However, the analysis of presented structures and the available data of their comparative agrotechnological assessment shows that some of the working bodies used make a significant amount of wet layers on daytime surface, the other part does not provide a stable soil tillage depth $(4-6 \mathrm{~cm})$ or does not destroy weeds during tillage $[5,6,7,8]$.

Table 1. Working organs for continuous shallow surface tillage

\begin{tabular}{|c|c|c|c|c|c|c|}
\hline \multirow[b]{2}{*}{ Types } & \multirow[b]{2}{*}{ Scheme of a working body } & \multicolumn{5}{|c|}{ Technological parameter } \\
\hline & & Name & $\begin{array}{l}\text { Gripping } \\
\text { width, cm }\end{array}$ & $\begin{array}{l}\text { Tillage } \\
\text { depth, } \\
\mathrm{cm}\end{array}$ & $\begin{array}{c}\text { Angle of } \\
\text { crumbling, } \\
\mathrm{cm}\end{array}$ & $\begin{array}{c}\text { Basic } \\
\text { tool }\end{array}$ \\
\hline \multirow{2}{*}{ I } & 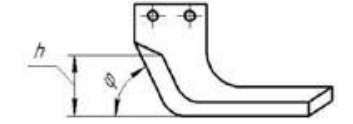 & $\begin{array}{l}\text { Narrow } \\
\text { one-sided } \\
\text { grip }\end{array}$ & 18,0 & $4-6$ & 15 & \multirow{2}{*}{ 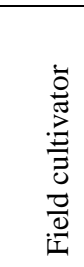 } \\
\hline & & $\begin{array}{l}\text { Stub's } \\
\text { element }\end{array}$ & 10,0 & $2-3$ & Changeable & \\
\hline \multirow{3}{*}{ II } & & $\begin{array}{l}\text { Flat- } \\
\text { cutting } \\
\text { pointed } \\
\text { grip } \\
\end{array}$ & 40,0 & $6-14$ & 15 & \multirow{3}{*}{ 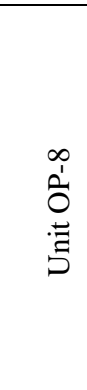 } \\
\hline & & Round rod & $180-200$ & $5-8$ & Changeable & \\
\hline & & $\begin{array}{c}\text { Rotation } \\
\text { roller }\end{array}$ & $180-200$ & $0-2$ & 0 & \\
\hline III & $=$ & $\begin{array}{l}\text { Flat- } \\
\text { cutting } \\
\text { one-sided } \\
\text { grip }\end{array}$ & 140 & 5 & 28 & $\stackrel{\bar{\theta}}{\bar{\Xi}}$ \\
\hline IV & & $\begin{array}{l}\text { Universal } \\
\text { pointed } \\
\text { grip }\end{array}$ & $38,5-33,0$ & $6-12$ & 28 & $\stackrel{\overline{0}}{\bar{\Xi}}$ \\
\hline V & & $\begin{array}{l}\text { Pointed } \\
\text { grip with } \\
\text { shank and } \\
\text { stabilizers }\end{array}$ & 22,0 & $6-12$ & 28 & $\stackrel{\overline{0}}{\bar{\Xi}}$ \\
\hline VI & & $\begin{array}{l}\text { Segmented } \\
\text { paired one- } \\
\text { sided grips }\end{array}$ & 35 & $6-8$ & 15 & 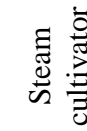 \\
\hline
\end{tabular}




\begin{tabular}{|c|c|c|c|c|c|c|}
\hline \multirow[b]{2}{*}{ Types } & \multirow[b]{2}{*}{ Scheme of a working body } & \multicolumn{5}{|c|}{ Technological parameter } \\
\hline & & Name & $\begin{array}{l}\text { Gripping } \\
\text { width, cm }\end{array}$ & $\begin{array}{c}\text { Tillage } \\
\text { depth, } \\
\mathrm{cm}\end{array}$ & $\begin{array}{c}\text { Angle of } \\
\text { crumbling, } \\
\mathrm{cm}\end{array}$ & $\begin{array}{c}\text { Basic } \\
\text { tool }\end{array}$ \\
\hline VII & & $\begin{array}{l}\text { Shank } \\
\text { paired one- } \\
\text { sided grips }\end{array}$ & 33 & $6-8$ & 15 & 志 \\
\hline VIII & 1 & $\begin{array}{c}\text { Flexible } \\
\text { working } \\
\text { body }\end{array}$ & 200 & 6 & 0 & 总 \\
\hline IX & & String & $30-40$ & up to 6 & 0 & 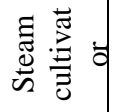 \\
\hline
\end{tabular}

In this regard, we propose the design of a new working body consisting of 2 narrow one-sided grips mounted on a holder, together with a chisel-shaped cutter (Figure 1). Such a combined working body can be installed either individually on the frame of the field cultivator, or several pieces on an additional frame with a chain suspension. The main element of the proposed combined working body for field cultivators is a one-sided standfree grip (right or left), which provides soil loosening to the required depth, including the minimum $(4-6 \mathrm{~cm}), 100 \%$ cutting of weeds and the removal of wet layers to the daytime surface. In addition to this, a "stub", which provides for compaction and mulching of the surface soil layer, is proposed (Figure 2).

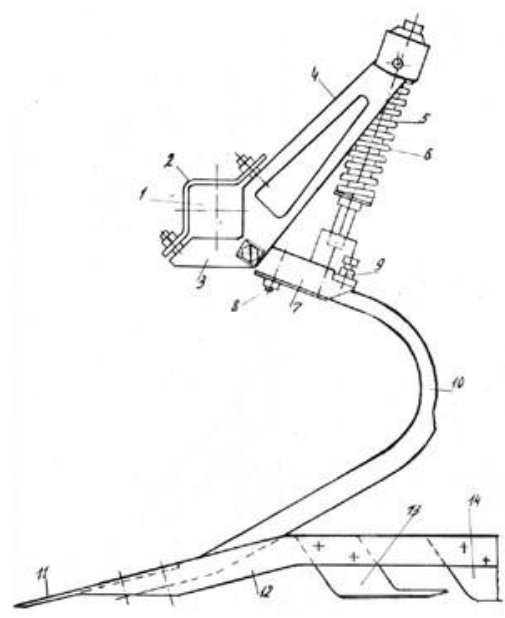

a)

1 - rack; 2, 3-pad; 4 -bracket; 5 - slat; 6 - spring; 7 - gearing; 8,9 - screws; 10 - stand; 11 - chisel; 12 - holder;

$$
13,14 \text { - grip }
$$

Fig. 1. Combined working body for a field cultivator

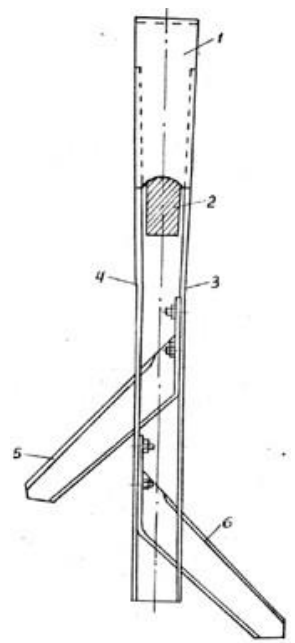

b)

1 - chisel; 2 stand;

3 - right sidewall of a holder;

4 - left sidewall of a holder;

5 - left unilateral arm;

6 - right unilateral arm 


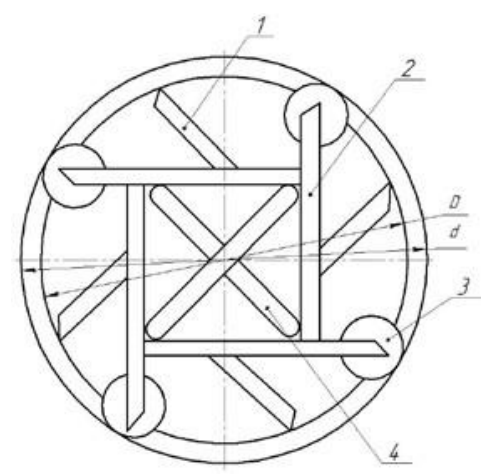

1 - tooth; 2 - blade; 3 - disk; 4 - chain link

Fig. 2. Stub to a field cultivator

\section{Selection of main parameters of working bodies for fallow fields tillage in the summer}

Rationale of the angle $(\gamma)$ of setting the lower part of the working body to the line of motion (Figure 3).

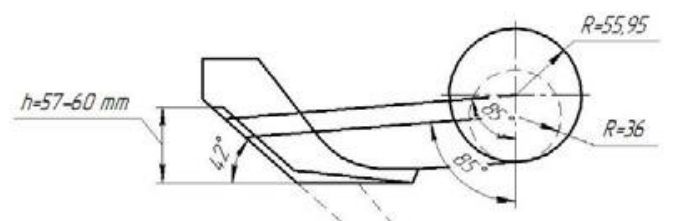

a

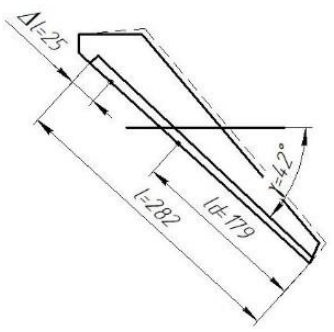

b
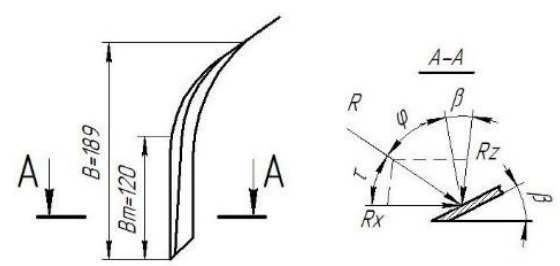

$\mathrm{c}$

a) side view; b) scan; c) front view; d) section A-A: forces acting on the horizontal part of a working body

Fig. 3. One-sided stand-free grip (element of a combined working body to a field cultivator)

$$
\sin \gamma=\frac{B_{1}+B_{\Pi}}{l-\Delta l-\frac{R \cdot \pi \cdot Q}{180}},
$$

where $B_{1}$ - width of strips tilled by the proposed working body (B1=90 mm); 
$V_{\mathrm{P}}-$ overlapping between working bodies $\left(V_{\mathrm{P}}=30-40 \mathrm{~mm}\right)$;

$l$ - length of a cutting edge of a working body $(l=282 \mathrm{~mm}-$ Fig. 3 in equation 9$)$;

$$
\operatorname{cg} \Theta=\frac{\sin \mu}{\operatorname{tg} \gamma_{0}} ; \Theta=85^{0}
$$

where $\mu$ - angle between lines of a bend and horizon $\left(\mu=5^{\circ}\right)$ (Figure $\left.3 a\right)$;

$\gamma_{0}$ - angle included between lines of a bend and the upper edge of a working body

$\left(\gamma_{0}=42^{0}\right)$

$\mathrm{R}$ - radius of conjugation of lower and upper parts of a working body.

$R_{\min }$ and $R_{\max }$ are determined from Figure $3 \mathrm{a}, \mathrm{b}, \mathrm{c}$.

$$
R_{\max }=\frac{180\left(l-\Delta l-l_{d}\right)}{\pi \cdot \Theta}=53,95(\mathrm{~mm}),
$$

where $\Delta l$ - length of cutting ridge of an upper bend from its upper end.

Under $R_{\max } \Delta l=23 \mathrm{~mm}$ (under $R_{\min } \Delta l=29 \mathrm{~mm}$ );

$l_{d}$ - actual length of a cutting edge of a working body from a lower inflection line to its end $\left(l_{d}=179 \mathrm{~mm}\right)$ Figure $3 \mathrm{~b}$.

$$
R_{\min }=(k \cdot a+a) \cdot 1,6=39(\mathrm{~mm}),
$$

where $k$ - coefficient for steels $30-65 \mathrm{G}-1,5-2,0$;

$a-$ steel thickness, $a=8 \mathrm{~mm}$.

1,6 - coefficient of preventing a crack appearance.

Then, the equation is (1) $\gamma_{\max }=42^{0} ; \gamma_{\min }=38^{0}$. So, the angle $(\gamma)$ of setting the lower part of the working body to the line of motion must be in limits $38^{0}<\gamma<42^{0}$.

\section{Justification of angles $(\alpha)$ and $(\varphi)$ of setting the upper part of the working body in transverse and longitudinally vertical planes and the horizon.}

The main purpose of the technological technique performed by the unit with the proposed working bodies is to create a tilled layer with a thickness of $h=55-60 \mathrm{~mm}$.

To determine the minimum and maximum angles $\alpha$ and $\varphi$ (Figure $1 \mathrm{a}, \mathrm{g}$ ), we use the expression:

$$
\sin \alpha(\varphi)=h / l_{B},
$$

where $h$ - thickness of the tilled layer, $h_{\min }=55 \mathrm{~mm} ; h_{\max }=60 \mathrm{~mm}$;

$l_{6}-$ length of the upper part of the cutting edge of the working body, $l_{6}=89 \mathrm{~mm}$.

Then, $\alpha_{\max }=42^{0} ; \alpha_{\min }=38^{0}$; and $\varphi_{\max }=42^{0} ; \varphi_{\min }=38^{0}$.

So, the upper part of the working body in the longitudinal-vertical plane should be set at the angle to the horizon within $38^{0}<\varphi<42^{0}$, and the angle of setting the upper part of the working body to the horizon in the transverse-vertical plane should be within $38^{0}<\alpha<42^{0}$. 


\section{Justification of the angle $(\beta)$ of setting the lower part of the working body to the horizon.}

To determine the maximum and minimum values of the angle $(\beta)$, we use the expression:

$$
\beta=90^{0}-\Psi-\varphi
$$

where $\Psi$ - angle between $R \kappa$ - horizontal component (Figure $1 \mathrm{~g}$ ) and $R$ - resulting component of all forces acting to the lower part of the working body;

$$
\Psi_{\max }=33^{0} ; \Psi_{\min }=30^{\circ} \text {; }
$$

$\varphi$ - angle of the soil friction to steel $31^{0}-42^{0}$.

Then, $\beta_{\max }=18^{0} ; \beta_{\min }=15^{0}$.

So, the lower part of the working body must be set to the horizon at the angle $15^{\circ}<\beta<18^{0}$.

The ratio of the radius $(\mathrm{R})$ of the interface of the upper and lower parts of the working body to the width of the working body (B) is obtained from the expression;

$$
0,2<R / B<0,3
$$

where $B=l \cdot \sin \gamma=189 \mathrm{~mm}$;

$\gamma$ - angle of the setting the working body to the line of motion $42^{0}$;

The general length of the cutting edge of the working body:

$$
l=l_{H}+l_{\Pi}+l_{B}=282 \mathrm{~mm},
$$

where $l$-general length of the cutting edge of the working body;

$l_{H}=B / \sin \gamma-$ length of the cutting edge of the lower part of the working body;

$l_{H}=B / \sin \gamma=134 \mathrm{~mm}$.

$l_{\Pi=}=B_{\Pi} / \sin \gamma=39,5 / \sin 42=59 \mathrm{~mm}-$ length of the cutting edge of the working body necessary to overlapping.

$l_{B}=\mathrm{h} / \sin \alpha=60 / \sin 42=89 \mathrm{~mm}-$ length of the cutting edge of the working body.

To check the obtained length of the working body for the possibility of the soil unloading in front of the working body, we use the dependence for it [9]:

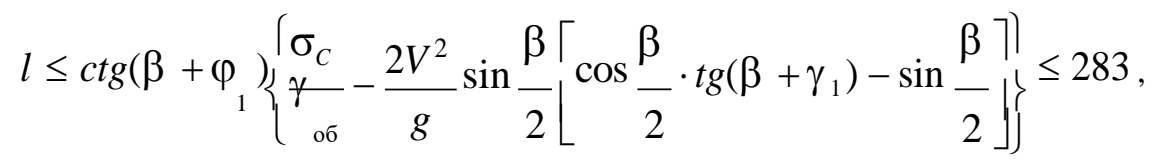

where $\beta$ - angle of crumbling, $\beta=15^{\circ}-28^{0}$;

$\varphi_{1}-$ angle of the soil friction to steel, $\varphi_{1}=31^{0}-42^{0}$;

$\sigma_{C}$ - temporal soil resistance to compression, $\sigma_{\mathrm{C}}=650 \mathrm{~g} / \mathrm{cm}^{2}$;

$\gamma_{\circ б}-$ soil volume weight, $\gamma_{о б}=2,4-2,7 \mathrm{~g} / \mathrm{cm}^{3}$;

$V$ - velocity of movement, $V=2,4-4,1 \mathrm{~m} / \mathrm{s}$;

$\mathrm{g}$ - acceleration of free falling; 
$l \leq 283$, that is $282 \leq 283$, and it indicates to the exclusion of soil unloading in front of the working body at selected parameters and speeds of movement. The relation of maximum $\left(R_{\max }=53,95 \mathrm{~mm}\right)$ and minimum $\left(R_{\min }=39 \mathrm{~mm}\right)$ radii of the interface of the lower and upper parts of the working body to the gripping width will be equal:

$$
\begin{aligned}
& R_{\max } / B=53,95 / 189=0,30 \\
& R_{\min } / B=39 / 189=0,20 .
\end{aligned}
$$

So, the ratio of the radius of the interfaces of the upper and lower parts of the working body to the gripping width must be within $0,2<(\mathrm{R} / \mathrm{B})<0,3$.

\section{Conclusion}

Based on the analysis of the design and technological schemes and parameters of existing working bodies, the compliance of their agrotechnological performance indicators with the requirements to work at depths of 4-6 cm without transfer of wet layers to the daytime surface, the technological task (project) was developed for the design of the combined working body, connecting elements, and a rolling-up device, there were made the model samples of new working bodies, and the preliminary field studies were conducted.

\section{References}

1. Pakhomov, V.I. Experience of winter wheat cultivation in conditions of insufficient moisture / V.I. Pakhomov, V.B. Rykov, S.I. Kambulov, N.V. Shevchenko, E.L. Revyakin. - Moscow, 2015. - 160 p.

2. Rykov, V.B. Development of efficient mobile technological units for the conditions of the South of Russia / V.B. Rykov, S.I. Kambulov, E.I. Trubilin, N.V. Shevchenko. Krasnodar, 2019. - 265 p.

3. Zonal systems of Rostov region agriculture for 2013-2020. - Part I. - Rostov-on-Don: 2013.

4. Zonal systems of Rostov region agriculture for 2013-2020. - Part II. - Rostov-on-Don: 2013.

5. Patent №1768012. Working body of a crawler / Taranin V.I., Zemlyansky B.A., Rykov V.B. // Claimed 29.10.1990. Published 07.10.1992.

6. Patent №2023355. Working body of a crawler / Taranin V.I., Koptev A.V., Rykov V.B., Afonin A.E. // Claimed 03.01.1992. Published 30.11.1994.

7. Patent №2023357. Soil tillage unit / Koptev A.V., Taranin V.I., Rykov V.B., Gasilin V.I., Afonin A.E. // Claimed 05.07.1991. Published 30.11.1994.

8. Patent №1802671. Anti-erosive soil tillage unit / Taranin V.I., Rykov V.B., Koptev A.V., Gasilin V.I. // Claimed 17.04.1991. Published 15.03.1993.

9. Sineokov G.I., Panov I.M. Theory and calculation of soil tillage units. - M.: Mechanical engineering, 1977. 